\title{
The Mackenzie Inuit Whale Bone Industry: Raw Material, Tool Manufacture, Scheduling, and Trade
}

\author{
MATTHEW W. BETTS ${ }^{1}$
}

(Received 14 June 2006; accepted in revised form 23 November 2006)

\begin{abstract}
The bones of bowhead whales (Balaena mysticetus) were used by Mackenzie Inuit groups in producing a number of items essential to transportation and procurement. However, the whale bone industry, and its relationship to Mackenzie Inuit economic and social systems, is poorly understood. A recently excavated archaeological assemblage from McKinley Bay, Northwest Territories, provides a record of intensive Nuvugarmiut whale bone tool manufacture, which can be used to reconstruct a reduction sequence. Bowhead bone reduction at McKinley Bay focused on ribs, which were transversely worked into large sections. Cortical blanks were isolated from central rib sections, but proximal and distal rib sections were treated directly as blanks and preforms for the production of large durable tools, such as harpoon heads, adze sockets, mattock blades, and picks. The intensive whale bone reduction at McKinley Bay was part of a broader gearing-up strategy focused on the manufacture and repair of sleds and harpoons needed for the late winter migration and spring seal hunt. More generally, because the whale bone industry was intimately related to the bowhead hunt and its proceeds, it may provide fundamental insights about key aspects of coastal whaling societies, such as social organization, redistribution, and inter-territorial trade.
\end{abstract}

Key words: Mackenzie Delta region, Inuvialuit, Mackenzie Inuit, bone tools, bowhead whale, reduction sequence, whaling, scheduling, trade, tool production

RÉSUMÉ. Les groupes d'Inuits du Mackenzie se servaient des os de baleines boréales (Balaena mysticetus) pour produire un certain nombre d'articles essentiels en matière de transport et d'approvisionnement. Cependant, l'industrie des os de baleine, de même que son lien avec les systèmes socioéconomiques des Inuits du Mackenzie, sont mal compris. Grâce à des fouilles archéologiques récentes à la baie de McKinley, dans les Territoires du Nord-Ouest, on a découvert une installation de fabrication intensive d'outils en os de baleine au Nuvugarmiut, ce qui a permis de reconstruire une séquence de transformation. La transformation d'os de baleines boréales à la baie de McKinley portait sur les côtes de baleine. Celles-ci étaient travaillées en grosses sections. Les pièces brutes corticales étaient isolées des sections de côtes centrales, tandis que les sections de côtes proximales et distales étaient traitées directement en tant que pièces brutes et ébrutées en vue de la réalisation de gros outils durables, comme des masses de harpon, des douilles d'herminettes, des lames de pioches ou de haches et des pics. La transformation intensive des os de baleine à la baie de McKinley relevait d'un programme plus important de fabrication et de réparation de traîneaux et de harpons dont les gens se servaient pour la migration de fin d'hiver et la chasse au phoque du printemps. De manière plus générale, puisque l'industrie des os de baleine était étroitement liée à la chasse à la baleine et à ses produits, elle pourrait permettre d'en savoir plus sur des aspects clés des sociétés baleinières de la côte, comme l'organisation sociale, le répartition du peuple et le commerce entre les territoires.

Mots clés : région du delta du Mackenzie, Inuvialuit, inuit du Mackenzie, outils en os, baleine boréale, séquence de transformation, chasse à la baleine, emploi du temps, commerce, réalisation d'outils

Traduit pour la revue Arctic par Nicole Giguère.

\section{INTRODUCTION}

The capture of a single bowhead (Balaena mysticetus) yearling, the preferred prey of Neoeskimo whalers (Savelle and McCartney, 1991, 1994), could provide up to $10000 \mathrm{~kg}$ of edible meat, blubber, and maktak (skin and attached fat). Yet a successful bowhead hunt was not only a caloric boon: the same yearling could provide hundreds of kilograms of high-quality baleen and bone as raw materials for tool production (Savelle, 1997). Both of these non-food yields were vitally important for Neoeskimo groups in northern regions. Bowhead bone, in particular, was used as a raw material in the manufacture of essential items, such as architectural superstructures, construction (i.e., digging) implements, transportation components, and hunting equipment. Bone was also used extensively in the production of domestic utensils (Whitridge, 2002) and figured prominently in the manufacture of ritual paraphernalia (e.g., Murdoch, 1892; Nelson, 1899). Indeed, whale bone remains an important northern resource today; it

${ }^{1}$ Archaeology and History Division, Canadian Museum of Civilization, 100 Laurier Street, Box 3100, Station B, Gatineau, Quebec J8X4H2, Canada; present address: Department of Anthropology, Idaho State University, Pocatello, Idaho 83209, USA; bettmatt@ isu.edu (C) The Arctic Institute of North America 


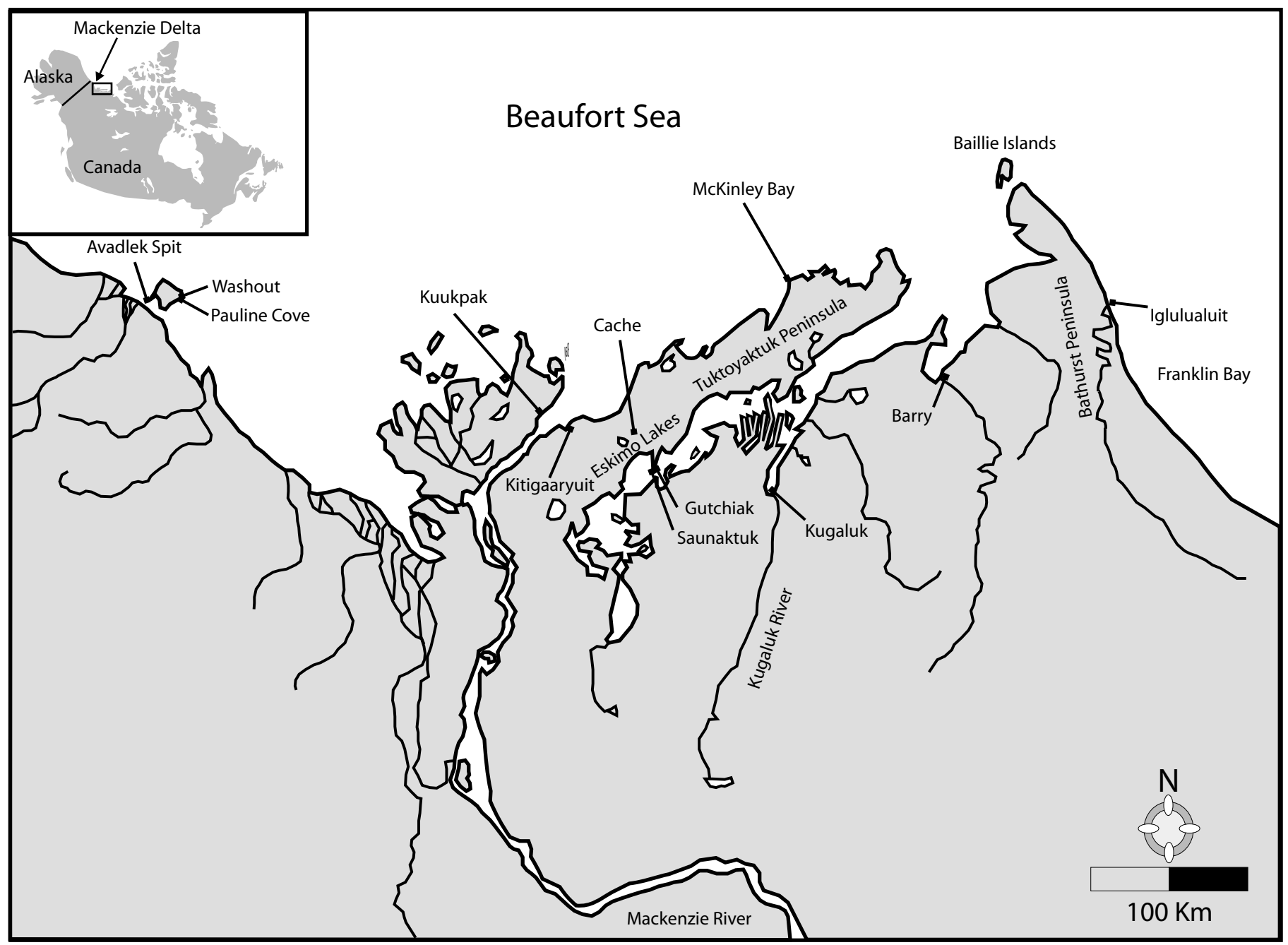

FIG. 1. Map of the Mackenzie Delta region, showing sites mentioned in text.

continues to be used as a carving medium by contemporary Inuit artists.

Bowhead bone has received increasing attention in recent scholarship. Researchers have investigated its use as an architectural element (Savelle, 1997; Levy et al., 2004), assessed its relationship to the social and ritual use of space (Whitridge, 2002), and revealed the effect of hunting and processing strategies on its deposition and distribution (e.g., McCartney and Savelle, 1985; Savelle and McCartney, 1991, 1994, 1999; McCartney, 1995). However, little attention has been paid to its use as an organic raw material in tool manufacture. This paper reconstructs the reduction sequences for key bowhead bone technologies associated with sled shoes, mattock blades, adze sockets, picks, and harpoon heads, largely on the basis of archaeological materials recovered from the McKinley Bay site, Northwest Territories. This design system is then compared to reduction sequences used by adjacent groups in the creation of caribou antler and bone tools (Morrison, 1986; Nagy, 1990, 1991; LeMoine, 1991, 1994). The potential importance of this unique whale bone industry to Mackenzie Inuit culture (ca. AD 1400-1850) is then explored in a preliminary fashion through the concepts of seasonal "gearing-up" (tool production) and inter-territorial trade.

\section{THE NUVUGARMIUT AND THE McKINLEY BAY SITE}

The McKinley Bay site (Borden designation OaTi-1) is located on a low sand bluff on what is essentially a sand bar that projects for approximately $1 \mathrm{~km}$ into the Beaufort Sea (Fig. 1). Unlike many coastal archaeological sites in the region, McKinley Bay is largely intact as a result of locally stable subsidence rates (Carmack and Macdonald, 2002: Fig. 13), although erosion has recently begun dismantling middens and buried activity areas west and south of the site (Betts, 2005b). The site was briefly tested and mapped in 1991 by Arnold (1992) as part of the Mackenzie Delta Heritage Project, and the present author returned in 2004 to conduct excavations as part of a larger research program aimed at reconstructing the socio-economy of Mackenzie Inuit bowhead whaling societies.

McKinley Bay was the location of a semi-permanent winter village and summer bowhead whaling camp inhabited 


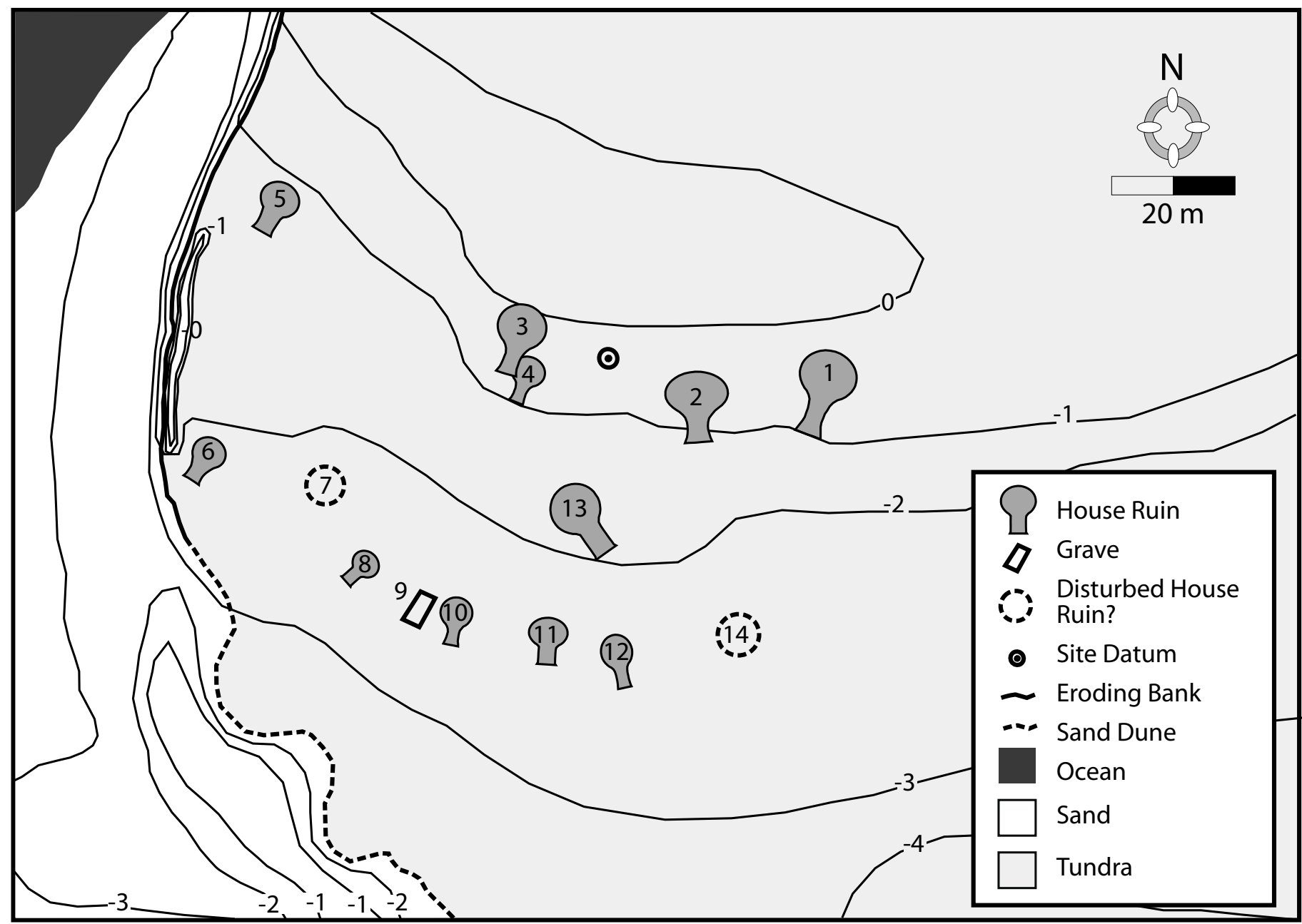

FIG. 2. Map of the McKinley Bay site.

by the Nuvugarmiut, one of eight distinct Mackenzie Inuit groups who occupied the Mackenzie Delta region from approximately AD 1400 to 1850 (Morrison, 1997; Betts, 2004, 2005a). By the latter half of the 19th century, Nuvugarmiut territory included all of the outer Tuktoyaktuk Peninsula and the northern Eskimo Lakes area, including the mouth of the Kugaluk River (Fig. 1). The Nuvugarmiut are described ethnohistorically as a coastal people who congregated to hunt bowhead whales at Nuvugaq, their main winter village (located approximately $20 \mathrm{~km}$ southwest of McKinley Bay), during the late summer and early fall. After the whaling season, most of the population briefly moved to the interior of the Tuktoyaktuk Peninsula to pursue migrating caribou. They reoccupied Nuvugaq by late fall or early winter, living there in semi-subterranean homes and subsisting on bowhead stores through the darkest days of the year. As extended daylight returned in late winter, groups moved to snow houses built on the sea ice, where they hunted seals at their breathing holes into the late spring (Richardson, 1851:257; M'Clure, 1969:87). Despite their seasonal mobility, the Nuvugarmiut maintained a clearly defined and defended border, and they were reticent to venture outside it for fear of violent encounters with adjacent territorial groups (Richardson, 1851:257; Stefansson, 2001:109).

The McKinley Bay site (Fig. 2) comprises 11 semisubterranean house depressions, roughly arranged in two rows oriented east-west. Arnold (1992) tested one of these houses (Feature 1), revealing a semi-subterranean log and turf structure with a carefully laid, log-lined floor and a deep entrance tunnel. The 2004 excavations at McKinley Bay were focused on Feature 2, a semi-subterranean house located adjacent to Feature 1 (see Fig. 2). While not the largest house mound at the site, Feature 2 covered approximately $80 \mathrm{~m}^{2}$. Though excavations were preliminary, more than one-third of the structure's interior was exposed. The excavations were carried out along two transects strategically selected to allow discernment of the dwelling's architectural configuration. They revealed a preserved, log-lined floor approximately $3 \mathrm{~m}$ wide, as well as three low benches (approximately $20-25 \mathrm{~cm}$ high). The north, or rear, bench was approximately $2.5 \mathrm{~m}$ long and $3 \mathrm{~m}$ wide. Excavations did not reveal the extent of the west and east platforms, although the shape of the interior depression suggests they were similar in size to the rear bench. A deep linear depression opposite the rear bench suggested the 
presence of an entrance tunnel, but this feature was not investigated. Preservation was excellent, with only minor root etching affecting osseous material recovered from active strata. A single AMS radiocarbon assay (Beta 201489) on a caribou mandible from the floor deposits suggests a calibrated date range for Feature 2 of AD 1521 1580 or AD $1626-1660$ ( \pm 1 SD). This dating is roughly contemporary with that for the occupation of Feature 1, where a terrestrial mammal bone recovered from floor deposits provided a calibrated date of AD 1482-1661 ( \pm 1 SD) (Arnold, 1992).

The analysis that follows is based primarily on materials recovered from Levels 3 and 4 of Feature 2. (Feature 1 is excluded from this analysis, as the structure lacked evidence for whale bone reduction.) Level 3 is essentially fill, composed entirely of roof and wall fall (logs and relict turves) that collected in the dwelling's interior as it collapsed. Level 4 consists of floor deposits in direct association with floor logs. These deposits are composed almost entirely of wood shavings and whale bone fragments, with artifacts, faunal remains, and other material strewn throughout (Fig. 3). Although in secondary deposition, the Level 3 deposit was likely created during the structure's use-life, and it is considered roughly contemporaneous with Level 4 (for discussion of these issues, see Stenton and Park, 1994; Friesen and Betts, 2005).

\section{WHALING AND WHALE BONE IN THE WESTERN CANADIAN ARCTIC}

Archaeological contexts from the Mackenzie Delta region, unlike those in the central Canadian Arctic, are not abundant in bowhead bone. The dearth of this material likely relates to three interconnected factors: 1) extreme taphonomic effects that operate on bowhead carcasses (e.g., McCartney and Savelle, 1985); 2) the exclusive use of driftwood, rather than whale bone, as a primary architectural element in Mackenzie Inuit dwellings; and 3) coastal erosion, which is destroying coastal village sites and associated bowhead butchery and flensing activity areas. Nevertheless, bowhead bone has been recovered in low frequencies from coastal locations where the whales were accessible, such as Washout (Yorga, 1980; Friesen and Hunston, 1994), Pauline Cove (Friesen, 1995), Avadlek Spit (Friesen, 1992; Betts, 2000), and Iglulualuit (Morrison, 1990). In a regional zooarchaeological assessment, Betts (2004, 2005a), argued for the presence of a focal whaling economy at these other coastal contexts and at McKinley Bay. Away from the coast, bowhead bone has been recovered from the beluga whaling sites of Kuukpak (Betts, 2001) and Kitigaaryuit (McGhee, 1974), both located on the East Channel of the Mackenzie River, and at inland fishing and caribou-hunting sites such as Kugaluk (Morrison, 1988), Saunaktuk (Arnold, 1990), Gutchiak (Morrison, 2000), Cache (Swayze, 1994), and Barry (Morrison and Whitridge, 1997; Morrison, 2000). Clearly,

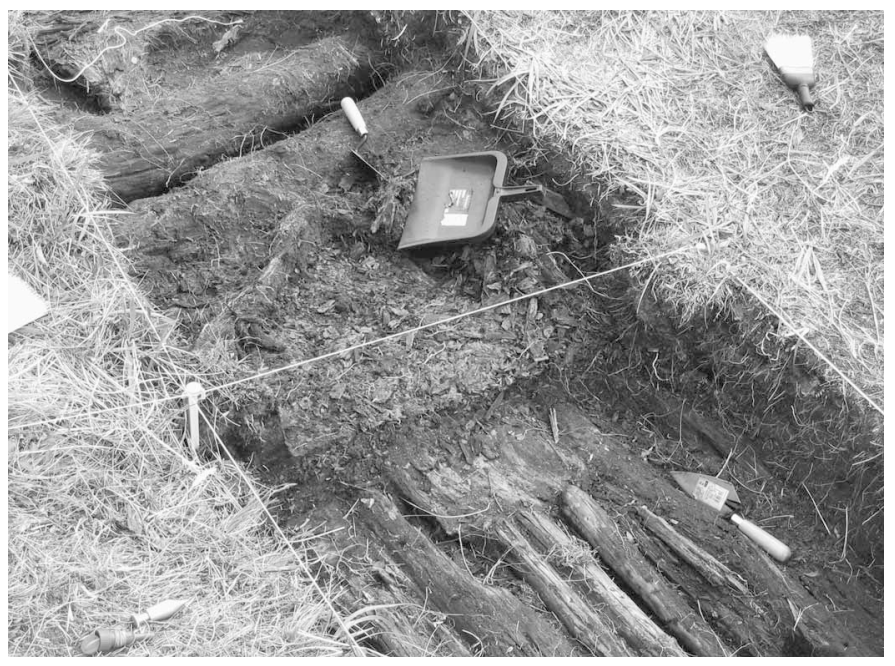

FIG. 3. Level 4 (floor) deposits in front of eastern bench, Feature 2, McKinley Bay.

despite severe taphonomic processes that operate against its recovery, bowhead bone occurs frequently in coastal contexts in the Mackenzie Delta region, and furthermore, it appears to have been transported to sites far removed from coastal bowhead-hunting locations.

McKinley Bay is located at an advantageous whaling promontory (Betts, 2005a), similar to Nuvugaq, where a major bowhead hunt was conducted in the early to mid19th century (e.g., Richardson, 1851; M'Clure, 1969; Stefansson, 2001). Ethnohistorical accounts provide details of how the bowhead hunt was structured and what happened to its proceeds. Richardson (1851) reported that the Nuvugarmiut pursued whales in the open water off the Tuktoyaktuk Peninsula over a six-week period in August and early September. M'Clure (1969) indicates that this hunt could be very successful; he reported that the Nuvugarmiut landed three bowhead whales in 1850. Farther east, at Baillie Islands, the Avvarmiut were also recorded as taking three whales in a season (Richardson, 1851). Whatever the productivity of the hunt, it is clear that it often generated a surplus. M'Clure (1969:87) states that the Nuvugarmiut traded baleen (or "whalebone") and whale oil to Mackenzie Inuit groups in the west, and Stefansson (2001) reports that a constant trade in subsistence products, including baleen, characterized relationships between the Nuvugarmiut and adjacent Kitigaaryungmiut (see also Morrison, 1997).

Baleen was, arguably, an essential material in Mackenzie Inuit society and was used in the manufacture of a suite of crucial items, including buckets and platters, toboggans, and bindings for various composite tools. Its most important use, however, was in the manufacture of nets for fishing, a critical economic activity for all Mackenzie Inuit groups (McGhee, 1974; Morrison, 1997; Stefansson, 2001; Betts, 2005a). Perhaps a measure of its value is that baleen recovered from sites outside of bowhead hunting areas is heavily worked, appearing as thin cut baleen strips or as part of finished artifacts (e.g., McGhee, 1974; Arnold, 
1990; Morrison, 2000). The presence of baleen shaves at riverine and inland sites such as Kitigaaryuit (McGhee, 1974) and Saunaktuk (Arnold, 1990) suggests that baleen was traded in raw form and then worked at these sites.

Like baleen, bowhead bone was a critical raw material, with structural properties that made it ideal for tools such as sled shoes and harpoons. At the macroscopic level, bowhead appendicular elements often lack a marrow cavity; the result is a much thicker cortical layer than is typically present in terrestrial mammal bone. Microscopically, whale bone has a more pronounced Haversian system (the network of spaces through which blood vessels ramify in bone) throughout the cortex. This trait gives whale bone its characteristic porosity and permits it to bear more load and absorb more energy before fracturing than comparable terrestrial mammal cortex (Scheinsohn and Ferretti, 1995: Table 3). These properties give bowhead bone a genuine advantage over antler or other terrestrial mammal bone in the production of tools. First, and most obviously, the size of bowhead bone elements and the thickness of the cortex make it naturally suited for the production of large organic tools, and second, the structural properties of the cortex allows for the manufacture of more durable implements. These properties likely explain why whale bone was especially favoured for the production of tools subjected to high degrees of stress, damage, or wear throughout the Western Arctic. Whaling and sealing harpoon heads, bird and fish spear prongs, bird bunts, mattock blades, picks, adze sockets, and sled shoes were all commonly made from whale bone (e.g., Giddings, 1952; Ford, 1959; McGhee, 1974; Yorga, 1980).

\section{REDUCTION AND TOOL MANUFACTURE AT McKINLEY BAY}

In contrast to lithic technology, the manufacture and use of bone tools in northern societies are poorly understood. Nevertheless, literature relating to bone tool reduction and use wear has steadily increased since Corbin's (1975) seminal work on Nunamiut bone technology (e.g., Nagy, 1990, 1991; LeMoine, 1991, 1994; LeMoine and Darwent, 1998) Fortunately, the Mackenzie Inuit bone tool industry is one of the best described for Arctic regions, and several studies are crucial for comparative purposes. The caribou antler reduction sequence developed by Morrison (1986) for the historic Nuvugarmiut is especially useful and provides a baseline reference for the whale bone reduction strategies defined here. A parallel reduction sequence defined for Qikiqtaryungmiut antler tools by Nagy $(1990,1991)$ is also informative. Finally, although not focusing on reduction per se, LeMoine's $(1991,1994)$ use-wear study of Mackenzie Inuit organic artifacts explores the local design system in considerable detail, giving special attention to the shaping and finishing of bone tools.

The whale bone sample recovered from the 2004 excavations at McKinley Bay consists of 1144 fragments of bowhead bone and 31 finished tools, sections, blanks, and preforms. Of the 31 worked pieces, 19 were recovered from Feature 2 and 12 were associated with eroding deposits on the beaches to the south of the site (see Fig. 2). The latter assemblage most probably relates to whale processing activities in the area where carcasses were hauled out on the beach (Betts, 2005b). While this assemblage may not be contemporary with the occupation of Feature 2, it nevertheless provides key evidence for element extraction and primary reduction (see below for definitions), and therefore it is included in the analysis below. Finished bowhead bone artifacts from the much larger, and consequently more diverse, Kitigaaryuit artifact assemblage (McGhee, 1974) are also referred to where appropriate in the following discussion.

Whale bone tools recovered from McKinley Bay include blunt arrowheads, sled shoes, harpoon heads, bird spear side prongs, gauged drills, adze sockets, and mattock blades. The majority of the debitage recovered from the Feature 2 floor deposits appeared as small to mediumsized bone chips, splinters, and fragments (Fig. 4A). In addition to the bone fragments, two complete anterior caudal vertebrae and a complete right humerus (all from a juvenile bowhead or bowheads) were recovered from the feature. Of the debitage, only a small percentage (ca. 8\%), consisting entirely of lateral rib fragments, may be confidently assigned to Balaena mysticetus. Smaller fragments and those lacking morphological landmarks were difficult to assign to a taxon below the order level (i.e., Cetacea) and therefore it is possible that they may derive from beluga whales, which also frequent this area of the Tuktoyaktuk Peninsula.

However, several differences in the structure of bowhead and beluga bone aid in the assignment of this fragmented material to bowhead whale. First, the cortical layer in bowhead bone is both proportionally thicker and denser (i.e., a result of a less pronounced Haversian system), leaving a clear separation between trabeculae and cortex, a feature often lacking in beluga bone. Bowhead cortex is often so thick that the proximal ends of ribs, for example, are practically devoid of trabeculated bone. In contrast, beluga cortex is typically thin and trabeculated bone frequently extends through it, giving beluga cortex a characteristic "spongy" appearance. Indeed, the higher proportion of trabeculated bone in beluga elements may have caused beluga bone to be regarded as a poor-quality raw material, and it does not appear to have been worked extensively even at large beluga whaling villages (e.g., Friesen, 1989; Betts, 2001; McGhee, pers. comm. 2006). Second, the trabeculae in the Haversian system in bowhead bone spongiosa are large and widely spaced, while those in beluga bone are smaller and more compactly spaced. Using these macroscopic distinctions between bowhead and beluga bone as a guide, and considering both the exceptionally small quantity of identified beluga bone recovered from McKinley Bay (only five specimens were identified), and the evidence of heavy working of the material, much of the 
fragmented cetacean bone from Feature 2 can be confidently assigned to bowhead whale.

A further problem is raised by the possibility that the highly fragmented deposit was created by processes other than tool manufacture, such as carnivore gnawing, butchery, and the production of bone grease. However, removal of meat from bowhead bones would not require the degree of heavy fragmentation encountered at Feature 2 (e.g., Monks, 2001). In addition, the very low incidence $(<0.5 \%)$ of charred and burnt whale bone, as well as the lack of any discernable hearth or cooking area in the excavations, suggests that grease production was not carried out within the house. Although carnivore activity is known to have a substantial effect on faunal fragmentation rates in the Mackenzie Delta region (Friesen and Betts, 2005), the extremely low incidence of gnawing on the whale bone $(<0.2 \%)$ suggests that this was not a serious taphonomic agent. In contrast, $5.4 \%$ of the bone exhibited evidence of chopping or "hacking" marks (Humphrey and Hutchinson, 2001). This percentage is low, but an order of magnitude greater than the proportion of fragments exhibiting heat alteration, gnawing, or both. Exclusion of these other taphonomic agents strongly suggests that the large quantity of fragmented bone is the result of intensive tool manufacture.

Most of the unidentifiable whale bone fragments recovered from Feature 2 likely derive from bowhead ribs. Many of the fragments are thick, square, or ovoid "slices" of bone, exhibiting two thick cortical surfaces sandwiched around a thin trabeculated layer, comparable in shape, size, and structure to a cross section of bowhead rib (Fig. 4E). The focus on working ribs in Feature 2 is congruent with the assemblage of "worked" bowhead bone recovered from other areas of the site, which was also dominated by ribs and rib fragments. The preferential use of these elements in tool manufacture is not surprising. Bowhead ribs, especially the proximal ends, have a high proportion of dense cortical material; they are relatively straight; and their length allows for the production of a multitude of large and small implements.

Given the rib-dominated nature of the McKinley Bay assemblage, the reduction sequence defined below is necessarily centred on preparing bowhead ribs for tool manufacture. It is intriguing that evidence of tool manufacture on other elements is lacking at McKinley Bay. While radii, humeri, and other dense long-bone elements were encountered both within Feature 2 and at eroding beach deposits, only one specimen, a large mandible, exhibited any evidence of working (see discussion below).

A point should be made here about the terminology used in the following narrative. A manufacturing action (see Corbin, 1975; Nagy, 1991) is defined here as a process of removing bone from a larger element or unit and is generally specific to both the type of raw material being worked and the stage of reduction of the tool. Nagy (1990, see also Morrison, 1986; LeMoine, 1991) has defined the manufacturing actions used by Mackenzie Inuit in antler and bone

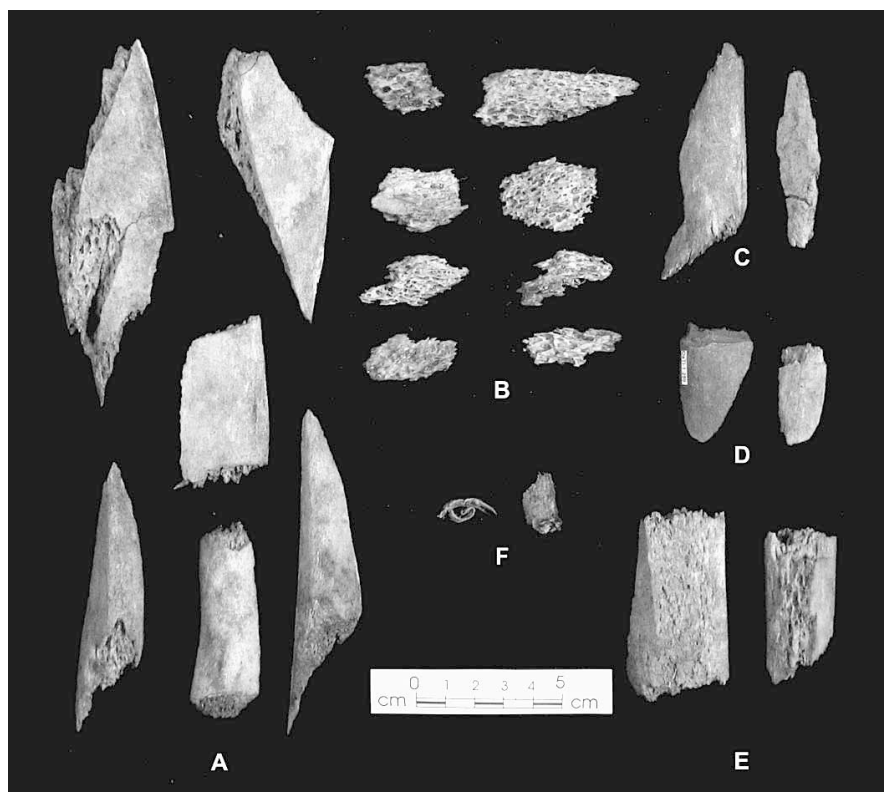

FIG. 4. Whale bone debitage from Feature 2, Level 4. A) lateral rib fragments, B) trabecular bone fragments, C) hinge fractured bone, D) bone flakes, E) rib cross-section fragments, F) bone shavings.

technology, which are generally consistent with those employed at McKinley Bay. These include chopping, chipping, grooving, drilling, snapping, whittling, grinding, and polishing. The terms are largely self-descriptive, and since detailed definitions have been previously provided by Nagy (1990:105-110), they are not reiterated here. A reduction stage may involve many manufacturing actions, and is defined as a fundamental step in the overall reduction sequence. These stages are generally specific to the shape and size of the bone element being worked and to the intended style and dimensions of the tool being produced. Note that the reduction stages defined below are heuristic devices specific to this study, and they may not entirely correspond with the Mackenzie Inuit toolmakers' concept of the tool production sequence (LeMoine and Darwent, 1998).

The reduction sequence identified below is divided into two coarse levels for organizational purposes, using terms borrowed from lithic analysis: primary reduction and secondary reduction (Yerkes and Kardulias, 1993). Primary reduction involves those actions that are intended to extract and prepare a raw material for tool production. They are essentially bulk reduction techniques used to produce cores and blanks. Secondary reduction involves the shaping and detailing techniques (actions) that give the tool its intended form and finish.

\section{Primary Reduction}

Morrison (1986) divides primary reduction into two sequential strategies. The first, transverse reduction, is necessary to reduce the length of bone elements. This process produces what are known as "sections" (Corbin, 1975; Nagy, 1990, 1991): bulky, minimally worked units 
of bone. Evidence of transverse reduction at McKinley Bay occurs in the form of large (ca. 20-60 cm) sections of ribs that exhibit marks indicating a "chop and snap" method of reduction (Morrison, 1986; Nagy, 1991). This manufacturing action involved roughly chopping the ribs around their circumference with a sharp, heavy tool until the trabeculated layer was exposed, and then breaking the bone by applying pressure on opposite sides of the cut.

The first step in transverse reduction of a complete rib was likely the removal of a distal rib section, which contained the most trabeculated bone, and hence was the lowest-quality portion of the rib. Next, ribs were chopped and snapped below the angle of the rib (Fig. 5), leaving the head, neck, tubercle, and angle as a single large proximal rib section. Sometimes, proximal sections were chopped and snapped a second time above the tubercle. Two proximal rib sections were thus isolated, one composed of the head and neck of the rib, and the other centred on the tubercle and angle of the rib. These divisions also freed a large, straight central rib section (Fig. 5), which could be anywhere from 30 to $70 \mathrm{~cm}$ in length, or even larger. No central rib sections were found intact at the site, a situation interpreted as a function of their quality as a raw material. The central section is the smoothest and straightest section of the rib, so it was likely the most desirable section for manufacturing cortical blanks (see below). Fig. 6 displays a sample of rib sections recovered from McKinley Bay.

The only other worked bowhead skeletal element recovered from the site, the proximal section of a left mandible, was also transversely reduced using the chop-and-snap technique described above. It is unclear whether the transverse reduction that occurred at McKinley Bay resulted from initial butchery and element extraction, or was a separate stage related to tool manufacture. Bowhead processing techniques used by groups in northern Alaska (see Vanstone, 1962; Whitridge, 2002) may have involved the separation during butchery of proximal rib sections, which would have been attached as "riders" to a butchery unit centred on the thoracic vertebrae. However, butchery does not account for the separation of the distal ends of the ribs, which would have been part, along with the central portion of the ribs, of a larger butchery unit associated with the chest and shoulder girdle of the whale (Whitridge, 2002). Therefore, it is possible that at least some of the transverse reduction at McKinley Bay, specifically the removal of proximal rib sections, occurred during butchery of the whale.

The surface evidence at McKinley Bay suggests that whales were flensed and processed on the beaches to the south of the site. In fact, a concreted, oily palaeosol, now largely buried by advancing sand dunes, was identified to the southeast of the site. This area of the site was so impregnated with oil that the oil continues to leach into an adjacent, and thoroughly polluted, tundra pond (refer to Richardson, 1851:258, for a similar description of whale oil pollution at Nuvugaq). Along with numerous caudal vertebrae and occasional fragments of skull, mandible, and forelimb bones, many proximal and distal sections of rib were recovered from the beaches to the south of this oilsoaked area, suggesting that much of the transverse reduction may have taken place there during the initial butchery of the animal. This interpretation is supported by the whale bone debitage recovered from Feature 2, which, as described below, is generally not consistent with transverse (i.e., first-stage) reduction.

Although three proximal rib sections were encountered on the beach, distal sections were more abundant $(n=9)$. Only proximal rib sections $(n=4)$ were recovered from within Feature 2. Not surprisingly, the evidence from the house indicates that the cortex-rich proximal and central sections were preferred for tool manufacture. Distal rib sections were not unusable, however, and were reserved for a few very specific types of artifacts.

The next primary manufacturing stage identified at McKinley Bay, longitudinal reduction, also has an analogue in antler reduction strategies (Morrison, 1986). Longitudinal reduction is intended to isolate the cortex of bulk sections of bone, and results in the production of both cores and blanks (see below for definition; also Corbin, 1975; Morrison, 1986; Nagy, 1990, 1991). At McKinley Bay, longitudinal reduction was accomplished by trimming the lateral edges of a rib with a heavy chopping or hacking implement. This left debitage in the form of flakes, splinters, and hinge-fractured bone composed of lateral margins of rib (Fig. 4A, C, D). The most distinctive debitage associated with this reduction occurred in the form of thin longitudinal sections of rib created by trimming the ribs after the removal of the outer cortex (Fig. 4E). This trimming would have created a tabular shaped rib core, defined here as a section of rib prepared for blank production. No rib cores were recovered from the McKinley Bay site.

After the rib core was isolated, it was split along the thin trabecular layer to create blanks, defined as isolated units of cortical bone ready for shaping into a specific tool. It is uncertain how this was accomplished at McKinley Bay. The cortical blanks recovered from Feature $2(n=4)$ show no direct evidence that they were isolated by grooving or drilling. However, two heavily used antler wedges were recovered from Feature 2 floor deposits, and these may have been used to split the cortical halves along the trabecular layer, in a way similar to splitting a long section of wood. Numerous fragments of trabeculated bone (Fig. 4B) indicate that once the cortical halves were isolated, excess spongiosa was chopped or chipped away from the cortex, leaving a long cortical blank. This activity left heavy chop marks on the cancellous margin of the cortical blanks, overlaying the scars left by lateral trimming (Fig. 7). These blanks were then transversely reduced a second time to the desired length by chopping and snapping. The longest cortical blank from Feature 2 was $55.2 \mathrm{~cm}$ long, and the smallest measured only $8.6 \mathrm{~cm}$. All were approximately $3 \mathrm{~cm}$ wide, a width comparable to that of whale bone sled shoes recovered from other Mackenzie Inuit sites in the region (McGhee, 1974; Yorga, 1980; Arnold, 1990). 


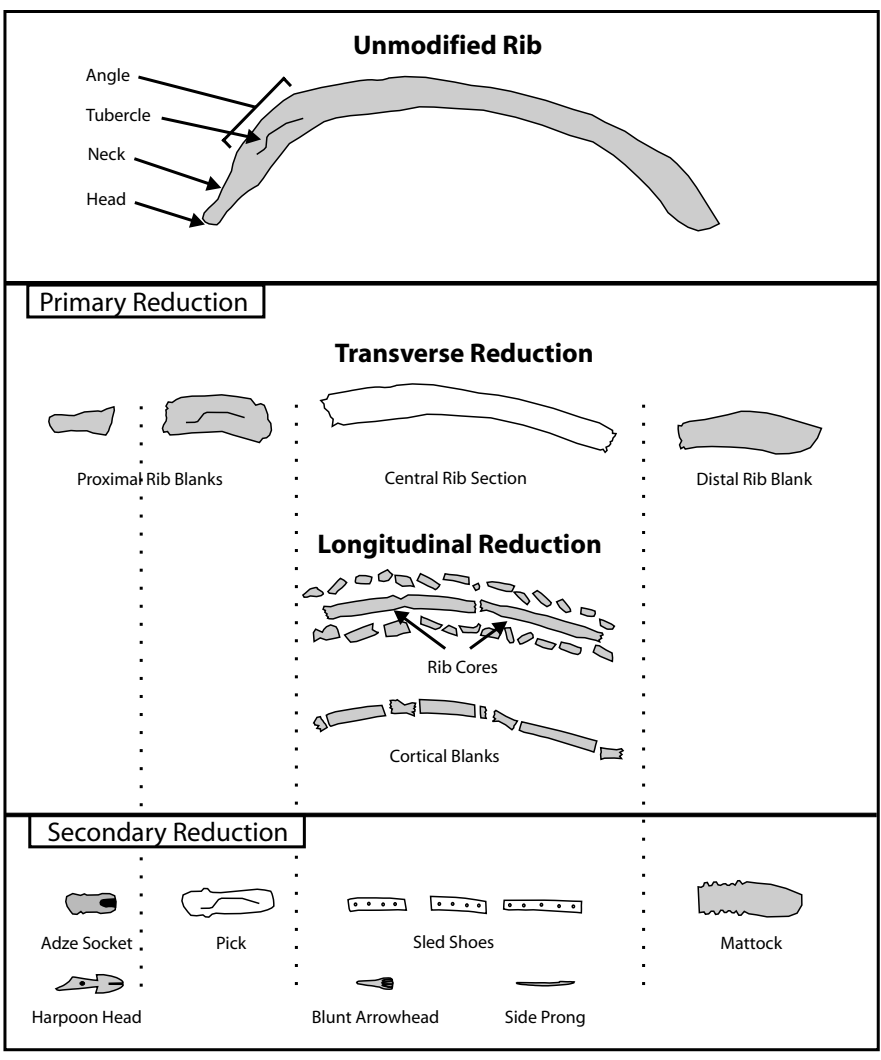

FIG. 5. Schematic representation of the rib reduction sequence. The gray items represent those recovered from McKinley Bay.

Longitudinal reduction appears to have been restricted to central sections of rib, as there is no evidence to suggest that proximal and distal rib sections were worked in this manner. The surfaces of the cortical blanks recovered from Feature 2 are devoid of landmarks characteristic of the proximal portion of ribs, and the debitage, especially the identifiable bone, is more consistent with the shape, thickness, and structure of central rib sections (proximal rib sections are primarily composed of cortical bone and exhibit complex morphology associated with the angle, head, and tubercle). No evidence of longitudinal reduction (in the form of debitage, cores, or cortical blanks) was discovered at any of the activity areas outside of Feature 2, implying that this activity took place primarily inside the dwelling.

\section{Secondary Reduction}

Secondary reduction techniques are aimed at transforming blanks into completed tools through shaping and finishing. Shaping and finishing can involve many manufacturing actions, including drilling, whittling, scraping, grinding, and polishing (Nagy, 1990, 1991; LeMoine, 1991). Evidence that secondary reduction took place in Feature 2 is present in several forms. First, whale bone shavings, consistent with waste created with scraping and whittling tools, were recovered from the floor deposits (Fig. 4F). Most importantly, four whale bone preforms (blanks reduced to the general shape and size of an in- tended tool) were recovered from the structure. The surfaces of two of these performs - a side prong and a Brower style harpoon head-are heavily faceted, suggesting they were whittled using a sharp, small bladed instrument, perhaps a crooked knife (LeMoine, 1991). Unlike the crisp whittling facets on the side prong preform, the edges of the facets on the harpoon head are rounded and blunt, suggesting that it was ground after whittling.

The remaining preforms recovered from Feature 2, two bird-spear side prongs, are fully ground and polished, but are nevertheless unfinished. One has incomplete barbs cut into it, while the other exhibits an unfinished drilled lashing hole. This generally suggests that grinding and polishing occurred before other manufacturing actions, such as drilling and incising. LeMoine (1991) has suggested coarsegrained grinding stones were used to roughly smooth bone surfaces, while finer buffing media, such as slate and leather, were used for fine polish. Examination of the specimens under low magnification suggests the use of a range of grinding media, from coarse to fine, to shape and finish the whale bone. This suggestion is consistent with the range of possible grinding and polishing stones recovered from Feature 2, which varied from fine-grained tabular "whetstones" to coarse, cone-shaped sandstone implements.

A primary shaping and finishing action carried out on whale bone (and other materials) from Feature 2 was drilling. Drilling technology accounts for more than $16 \%$ of the entire recovered artifact assemblage, including 24 complete or fragmentary gauged bone drill bits, two wooden drill spindles, and a heavily worn bow drill mouthpiece. Perhaps significantly, many of the recovered drill bits were made from bowhead bone, and unfinished tangs and shafts of these implements suggest that most were created from cortical rib blanks, or perhaps recycled from spent or broken tools previously manufactured from cortical blanks.

The types of implements that were worked with drilling technology are suggested by the blanks, preforms, and artifacts recovered from Feature 2, as well as by the size of the drill gauges themselves. For instance, the whale bone harpoon head preform (Brower style, see Ford, 1959:90) would have been finished by drilling a large socket and line hole and several small contiguous pilot holes to create a blade slot (a blade slot on an antler Nuwuk harpoon head from Feature 2 was created in this fashion). Most of the drill bits recovered from Feature 2 are ca. $7 \mathrm{~mm}$ in diameter, a large gauge that could have produced the size of line and socket perforations found on Nuwuk, Barrow, and Thule 4 harpoon heads recovered from both McKinley Bay (Arnold, 1992; Betts, 2005b) and Kitigaaryuit (McGhee, 1974). Smaller bits ca. $2 \mathrm{~mm}$ in diameter, the appropriate size for drilling blade slot pilot holes, are also present in the assemblage. Interestingly, beyond the drilling paraphernalia, many of the bone and antler harpoon heads and bone harpoon endblades recovered from the feature are grooved and snapped, suggesting a larger preoccupation with harpoon maintenance and repair activities. Significantly, harpooning technology formed the largest proportion (38\%) 




FIG. 6. Rib sections recovered from McKinley Bay. From top to bottom, proximal rib section, proximal rib section composed of neck and head of rib, proximal rib section composed of angle and tubercle of rib, distal rib section.

of the procurement technology recovered from Feature 2. This evidence, in conjunction with the drilling technology and preforms found in the house, suggests a focus on production, maintenance, repair, and recycling of sea mammal hunting gear.

Other tools were also worked with drilling technology at the site. For instance, the larger size gauged drills (ca. $7 \mathrm{~mm}$ ) are also consistent with the size of holes used in the production of sled shoes. The long bowhead bone cortical blanks recovered from Feature 2 are perfectly proportioned for sled shoe manufacture, and, as discussed above, the bone debitage indicates the production of these blanks was a primary focus of bowhead bone reduction in the structure. Additionally, two long antler cortical blanks, similar in dimensions to the bowhead specimens, a complete (but spent) antler sled shoe, and a re-worked antler sled shoe fragment were recovered from Feature 2. In sum, the abundance of large-gauge drilling technology, the focus on the production of long whale bone (and antler) cortical blanks, and the evidence of production and repair of antler sled shoes strongly suggest that sled shoe manufacture and maintenance were also intensively conducted in Feature 2. Only eight fragments of antler debitage were recovered from the feature, in contrast to over 1000 fragments of bowhead bone debitage, indicating that bowhead bone was likely the primary focus of this activity.

Bowhead bone was also transformed into other tool categories at McKinley Bay. Although these other tools are represented only by complete and finished artifacts, the structure of the raw material also provides some clues about the reduction sequence used to create them. For example, the single large adze socket from Feature 2 was composed entirely of cortical bone, with no evidence of a trabeculated layer. The specimen is so thick that, if constructed from a whale rib, it could have come only from the thick cortex at the rib's proximal end. In comparison, bowhead bone adze sockets from Kitigaaryuit were some-

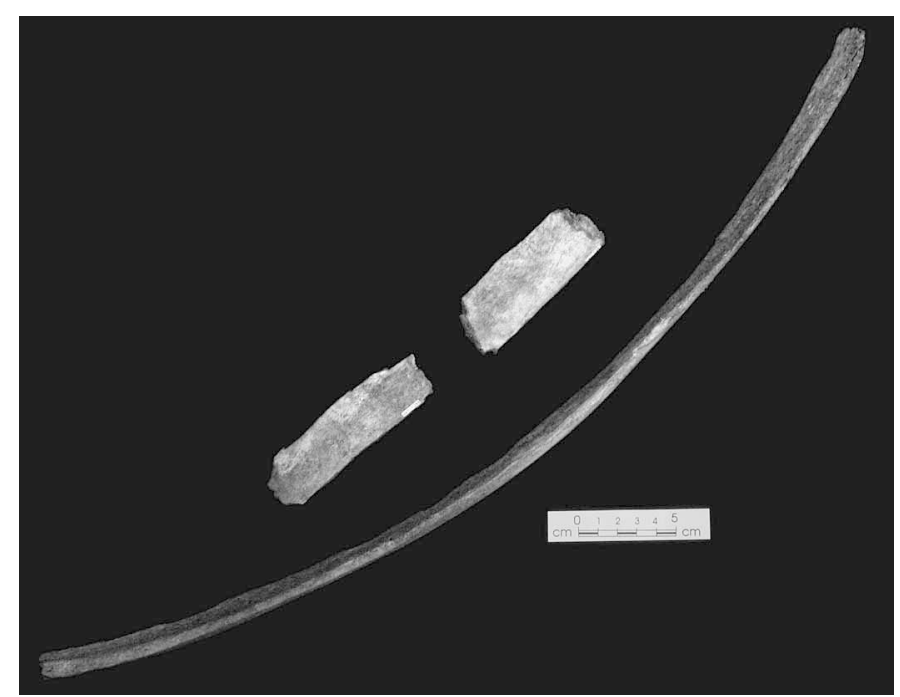

FIG. 7. Examples of cortical blanks recovered from Feature 2.

times constructed directly from the proximal head and neck portion of rib (the proximal articular surface is intact on one specimen [McGhee, 1974: Plate 12f], while remnant tubercles can be identified on others [McGhee, 1974: Plates 12, 21]; see also Fig. 8 for comparison). The McKinley Bay adze has a closed socket, which appears to have been first drilled and then whittled out with a sharp instrument. While Kitigaaryuit examples typically have an open socket, these sockets were also drilled and whittled into shape (e.g., McGhee, 1974: Plate 12f).

Harpoon heads, especially whaling harpoon heads, were likely also manufactured from proximal rib sections. The cortical blanks recovered from Feature 2, though thick, were simply not thick enough for the manufacture of harpoon heads. Furthermore, the large Brower harpoon head preform (Ford, 1959) recovered from Feature 2 exhibited no evidence of trabeculated bone, suggesting it was created from the thick cortex of a proximal rib section. No evidence of longitudinal reduction of proximal or distal rib sections was recovered from the site, indicating that such large tools were created directly from unmodified rib sections. For instance, one of the proximal rib sections recovered from Feature 2 (see Fig. 6), consisting of the head and neck of the rib, is similar in size to the large Brower harpoon head preform recovered from the structure. Composed entirely of dense cortical material, this section would have made an eminently suitable blank for a harpoon head or similarly sized object. If this interpretation is correct, and harpoons were manufactured directly from proximal rib sections, the manufacturing sequences used to create harpoon heads and adze sockets from whale bone are strikingly similar (see Appendix).

Many of the large whale bone artifacts used by the Mackenzie Inuit also appear to have been manufactured in this manner. Although no bowhead bone picks were recovered from McKinley Bay, examples from Kitigaaryuit (McGhee, 1974: Plate 7n, 12a) were manufactured directly from proximal rib portions, with the neck tubercle 
still visible (Fig. 8). Large tools were also created from distal rib sections without prior reduction. The comparison of a mattock recovered from Kitigaaryuit (McGhee, 1974: Plate 19a) with a distal rib section recovered from McKinley Bay clearly demonstrates that this section of rib was used to produce this artifact class (Fig. 9). While the single mattock recovered from McKinley Bay is more formally constructed in comparison to the Kitigaaryuit specimen, the trabeculated nature of the raw material is consistent with the osseous structure of distal rib sections. Consequently, because artifacts were often shaped directly from these units, proximal and distal rib portions are likely more appropriately referred to as blanks, rather than sections or cores (see Appendix).

It is not clear how, or whether, the cortex-rich bowhead proximal rib sections were subjected to longitudinal reduction (i.e., blank extraction) for the construction of smaller implements, such as the bird spear side prongs and bird bunts recovered from McKinley Bay. Given the size of these smaller tools, it is possible that the majority were crafted from cortical blanks isolated from central rib sections. In fact, a bird spear prong preform recovered from Feature 2, in the initial stages of shaping, exhibited remnants of chop marks consistent with the lateral trimming used in cortical blank production. Nevertheless, it is possible that smaller bowhead bone artifacts, like the larger adze heads and harpoons, were whittled directly out of large pieces of proximal rib, particularly the head and neck portion.

\section{COMPARISONS WITH THE MACKENZIE INUIT ANTLER AND BONE INDUSTRIES}

The Mackenzie Inuit bowhead bone industry employed the same basic suite of manufacturing actions and stages used in terrestrial mammal bone and antler technologies. These manufacturing techniques represented a conceptual tool production system shared by all Mackenzie Inuit tool producers (LeMoine, 1991). Nevertheless, there are several important differences between the antler and whale bone reduction sequences. First, the primary reduction of bowhead ribs invariably involved chopping and breaking; there is no evidence to suggest that ribs were reduced using any other manufacturing action. This is in clear contrast to antler and bone reduction strategies used by the Nuvugarmiut at the inland site of Kugaluk (Morrison, 1986), where groove-and-snap and drill-and-snap methods (as well as sawing) were employed in both transverse and longitudinal reduction (see also Nagy, 1990, 1991). It is possible that these differences in manufacturing actions used during primary reduction relate principally to bone structure. Given the thickness and density of bowhead cortex, grooving or drilling to free sections or blanks would have been a difficult and time-consuming process. In fact, grooving and drilling would have been extremely inefficient on proximal portions of ribs, where there is virtually no trabeculated bone.

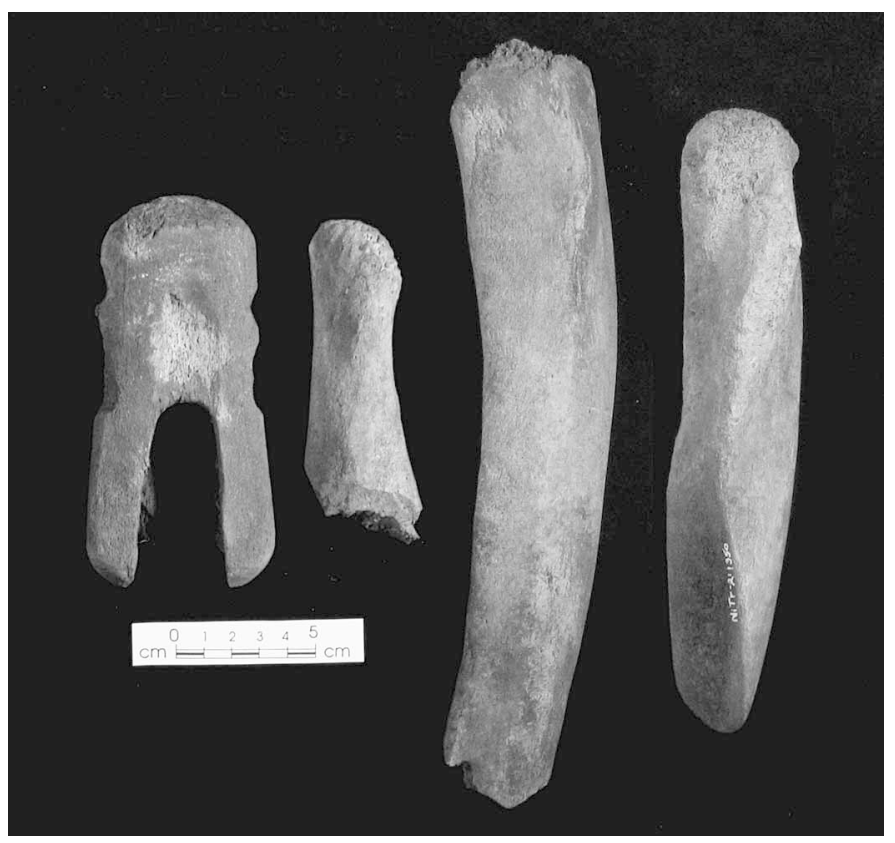

FIG. 8. A whale bone adze socket and pick, and the corresponding proximal rib sections from which they would have been manufactured. The rib sections were recovered from McKinley Bay; the finished artifacts from Kitigaaryuit.

There are also differences in the way sections, cores, and blanks were produced on bowhead bone and antler. Morrison (1986) noted that at Kugaluk, transverse reduction was exclusively an antler core production technique, which indicates that transverse reduction was used primarily to isolate the thick antler cortex for later longitudinal reduction and blank preparation (e.g., Morrison, 1986; Nagy, 1991: Fig. 6). In contrast, Morrison suggests that transverse reduction was not necessary on terrestrial mammal long bones because their thinner cortex was naturally sized for blank production. Long bones were therefore treated directly as cores and were subjected only to longitudinal reduction, typically using the groove and snap method. Like antler, bowhead bone is composed of a much thicker cortical layer than most mammalian bone and often lacks a marrow cavity, so it is not surprising that bowhead ribs were subjected to high levels of transverse reduction. However in the bowhead bone reduction sequence, unlike the antler reduction sequence, only a specific portion of the rib, the central rib section, was subjected to longitudinal reduction and subsequently transformed into cores and blanks. Proximal rib sections (with cortex as thick, and usually thicker, than antler) and distal rib sections were apparently not longitudinally reduced; they were simply used directly as blanks (and sometimes preforms) for large tools. This procedure has no direct analogue in terrestrial mammal bone or antler reduction sequences from the region (Morrison, 1986; Nagy, 1990, 1991).

Many of the differences between the reduction sequences appear to relate to the types and sizes of tools created from bowhead bone. During the production of some particularly large tool types, such as picks and mattock blades, proximal and distal rib sections simply 


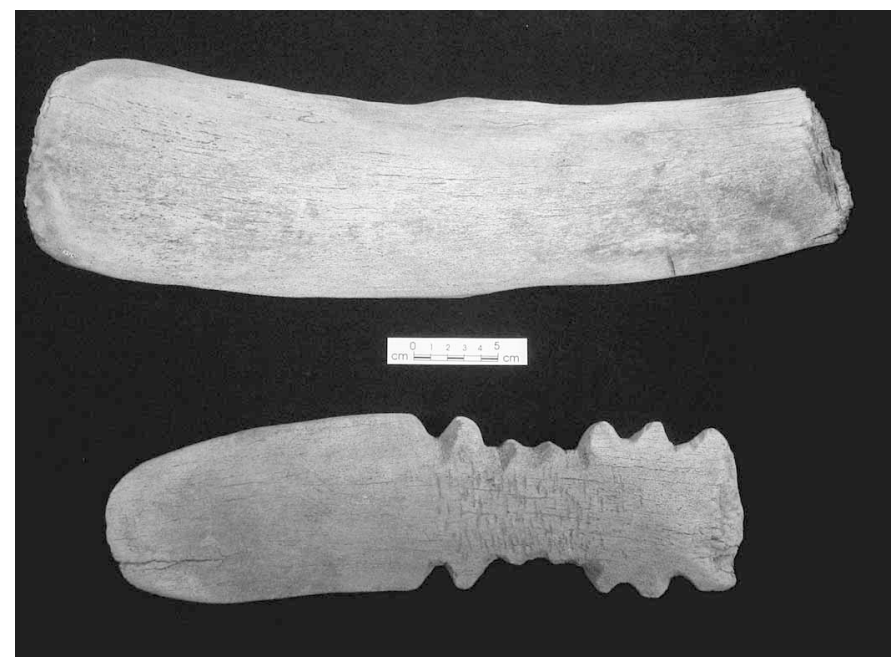

FIG. 9. A whale bone mattock (bottom) recovered from Kitigaaryuit, compared to a distal rib section (top) recovered from McKinley Bay.

had to be treated directly as blanks. In fact, less formal, or very large, styles of picks or mattocks often involved very little shaping of the bone, and the rib sections appear to have been treated directly as preforms. This type of section-to-tool production appears to have been used for other tools as well, such as adze sockets and large harpoon heads. Put simply, the Mackenzie Inuit appear to have selected the most efficient raw material, in size and structure, for the production of these large, heavy-use artifacts.

\section{DISCUSSION}

Though focused on the definition of Nuvugarmiut bowhead bone reduction strategies, the foregoing analysis raises several interesting questions about the position of raw materials and tool production in prehistoric Mackenzie Inuit society. The first and perhaps most intriguing question relates to the evidence for intensive tool manufacture in Feature 2 at McKinley Bay. Why was this production so intensive, and why was it predominately focused on manufacturing and maintaining sledding and harpooning gear? A second question relates to the presence of bowhead bone artifacts at sites such as Kitigaaryuit, where bowhead whales were not accessible. What does the presence of this material outside of the Nuvugarmiut home territory indicate about access to bowhead products by Mackenzie Inuit groups who did not participate in the hunt?

In regard to the first question, production of curated tools (items preserved for indefinite use) like those made at McKinley Bay is often carefully organized logistically; as Binford (1977) notes, curated tools are often more complex, frequently composite, and therefore require greater investments of labour to manufacture. Hence, when curated tools are needed in quantity for a particular task, they are often produced in advance and stockpiled until they are needed. Such a seasonal production strategy, also known as "gearing-up" (Binford, 1977; Whitridge, 2001), would have been a crucial logistical necessity for huntergatherer groups that relied on intensive exploitation of seasonally heterogeneous resources.

Many Mackenzie Inuit winter houses show evidence of seasonal production, or "gearing-up." Betts (2004), comparing the number of species-specific hunting implements recovered from Mackenzie Inuit winter houses to their associated faunal frequencies, noted that most of those houses contained more tools used in spring, summer, and fall hunts than tools used in winter procurement activities. It is possible, therefore, that the whale bone tools manufactured at McKinley Bay were primarily related to gearingup strategies.

Ethnohistoric evidence clearly indicates that Nuvugarmiut abandoned their semi-subterranean houses in late winter to hunt seals on the sea ice until late spring (Richardson, 1851). Sledding equipment, and especially semi-disposable sled shoes, would have been essential for a late winter migration over rough sea ice and snow, and also for the return migration to the Tuktoyaktuk interior in late spring or early summer. The raw material (large sections of bowhead bone or antler) needed to make and repair sled shoes would not be readily available on the sea ice and was bulky to transport. Therefore, the production of a stock-pile of ready-made sled shoes before the spring migration was advantageous. A stockpile of harpoon heads (both bone and antler) would also have been crucial to the success of the seal hunt, since hunters had little time to craft these tools during the busy sealing season (e.g., Damas, 1969); indeed, material taboos may have prohibited it (e.g., McGhee, 1977). The intensive bowhead tool manufacture that occurred at McKinley Bay, which included sledding and sealing paraphernalia, is consistent with a pre-production or gearing-up strategy for this crucial seasonal shift in Nuvugarmiut lifeways.

While intensive production of organic tools at McKinley Bay was probably linked to seasonal tool production, it may also have reflected the complex socioterritorial system of redistribution and trade in which the Nuvugarmiut are known to have participated (Morrison, 1997). Bowhead bone was essential for the construction of large bone tools, and its structural qualities were suited for the manufacture of durable equipment that could withstand high levels of force, whether percussive (adze sockets, mattocks, picks), ballistic (bird bunts, harpoon heads), or frictional (sled shoes, drill bits). Given these qualities, there can be little doubt that bowhead bone was a highly desired raw material throughout the region.

Ethnographic information on the traditional trade networks of the Mackenzie Inuit is scant, but a few references do shed some light on the connections involved. Stefansson (2001) describes a lively trade between the Nuvugarmiut and the Kitigaaryungmiut for subsistence items such as caribou, seal, beluga, and fox skins, as well as items of Euro-American manufacture. M'Clure (1969) also indicates that the Nuvugarmiut traded baleen and whale oil to adjacent groups, although he is not specific about which 
groups participated in the trade network. Betts (2005a) speculated that these trade networks extended into the prehistoric period as well, suggesting that they were necessary, in the context of a highly segregated (i.e., territorial) economic system, to distribute crucial subsistence commodities throughout the region.

Little is understood about prehistoric trade commodities in the Mackenzie Delta region (although see Friesen, 1995), but bowhead bone artifacts have been recovered from several inland and riverine locations where the whales could not have been hunted, among groups whose seasonal round precluded a bowhead hunt. These include the Imaryungmiut settlements of Gutchiak (Morrison, 2000) and Saunaktuk (Arnold, 1992), and the Kitigaaryungmiut village of Kitigaaryuit (McGhee, 1974). The Gutchiak and Saunaktuk assemblages date to ca. AD 1400, around the time of the Thule/Mackenzie Inuit transition (see Betts, 2005a), and therefore may be too early for direct comparison to McKinley Bay. However, the assemblage recovered from Kitigaaryuit is Mackenzie Inuit in age (McGhee, 1974) and should provide an adequate comparative sample.

It is unlikely that the bowhead bone recovered from Kitigaaryuit was obtained by Kitigaaryungmiut passing through the territories of other coastal groups, or that it was directly procured by Kitigaaryungmiut participating in a bowhead hunt. Though they shared a border with the Nuvugarmiut, relationships between the groups were apparently hostile (e.g., Richardson, 1851), a situation that generally characterized relations among all the groups in the region (Morrison, 1997). Furthermore, the overlapping schedules of the bowhead and beluga migrations prohibited Kitigaaryungmiut participation in a coastal bowhead hunt when they would have been busy hunting and processing beluga on the East Channel of the Mackenzie River. Indeed, the prestigious nature of the coastal bowhead hunt (e.g., Savoie, 1970), coupled with the extreme segregation and control of resources and resource locations by each territorial group (Betts, 2005a), makes such a possibility very unlikely. The only other explanation is that this material was traded between coastal groups like the Nuvugarmiut and riverine groups like the Kitigaaryungmiut.

An examination of the larger Kitigaaryuit artifact assemblage at the Canadian Museum of Civilization revealed 32 specimens derived from bowhead bone, including 29 finished artifacts, two preforms, and one cortical blank. The most abundant tools in the assemblage are sled shoes (25\%), adze sockets (20\%), mattocks/picks (17\%), and harpoon heads (14\%). In sum, the artifact assemblage is generally consistent with the types of heavy-duty artifacts one would expect to be constructed of bowhead bone, and closely resembles the range of tools manufactured at McKinley Bay. An interesting enigma is therefore presented by the possibility that these tools either a) arrived at Kitigaaryuit as finished artifacts, or b) were manufactured by Kitigaaryungmiut from traded raw material.

The bowhead bone preforms recovered from Kitigaaryuit are not informative in this regard. Both are small, heavily faceted ovoid or rectangular pieces of cortex obviously intended for fish lures. Each could have been recycled from another type of artifact, such as a spent adze socket or mattock. The cortical blank, which was isolated from a proximal rib section, is consistent with the longitudinal rib reduction identified at McKinley Bay; however, it is noteworthy that proximal rib sections appear not to have been longitudinally reduced by the Nuvugarmiut. Furthermore, the Kitigaaryuit blank was isolated by grooving and snapping, rather than the chop-and-snap technique used at McKinley Bay. This discrepancy might have occurred if the blank had been manufactured from a broken or spent pick, using longitudinal reduction techniques familiar to the Kitigaaryungmiut from working antler and terrestrial mammal bone (e.g., Morrison, 1986; Nagy, 1990, 1991). It might also have occurred if the proximal rib section had been traded as raw material, or if it had arrived as part of a traded butchery unit. As described above, proximal bowhead rib sections may have been attached as riders to a butchery unit centred on thoracic vertebrae (e.g., Whitridge, 2002); yet this butchery unit, with bone included, would have been too heavy to be traded over any significant distance, if at all. More realistically, it is likely that both finished artifacts and raw material were traded between the groups. As with any subsistence product, the amount and type of material traded probably fluctuated according to a myriad of production and consumption factors that affected the amount of surplus raw material and finished tools the Nuvugarmiut could allocate for trade.

Finally, the spatial distribution and composition of whale bone assemblages at McKinley Bay may lead to inferences about social organization at the site. The lack of evidence for bowhead bone tool manufacture at Feature 1, and indeed the lack of any bowhead bone elements there at all, may relate directly to social aspects of the bowhead hunt and access to its proceeds. Radiocarbon dates (see above) indicate that the two structures are relatively contemporary, suggesting they may have been occupied concurrently. If this is correct, then the lack of bowhead remains in Feature 1 may indicate differential access not only to raw material, but perhaps to the bowhead hunt itself. In North Alaska, successful umialit (whaling captains) and their wives redistributed specific butchery units (which included meat, blubber, maktak, and bone) to individuals and families according to their degree of participation in the hunt, following tightly prescribed rules (e.g., Vanstone, 1962; Whitridge, 2002). In such a situation, it is possible that the inhabitants of Feature 1, because of their specific and recurring role in the hunt, did not have access to portions of the whale that included bones with high manufacturing utility.

The lack of evidence for worked elements other than ribs at Feature 2 also suggests differential redistribution of the whale carcass. However, this suggestion is tempered by the lack of evidence for other worked bone elements anywhere at McKinley Bay. In fact, despite the presence of hundreds of other suitable bone elements observed from subsurface 
and surface deposits, only one other element type, represented by a single bowhead mandible, exhibited modification. Regardless, in North Alaska differential distribution of portions of the whale carcass by the umialik and his wife may have resulted in a situation where households consistently accumulated unique element assemblages associated with specific butchery units (Whitridge, 2002). If a similar redistributive system was practiced by the Nuvugarmiut, then perhaps Feature 2 represents a household that received primarily butchery units with attached rib portions. Indeed, the element distribution from Feature 2, composed of ribs and humeri (associated with the silvik portion) and caudal vertebrae (associated with the sulugak portion), is consistent with the butchery units typically distributed in North Alaska to the second or third boat that participated in striking or towing a whale (Whitridge, 2002).

\section{CONCLUSION}

In conclusion, the above analysis, while preliminary, suggests that the study of bone tool industries can lead to insights about central aspects of whaling societies. First, the reduction sequence appears to have been fundamentally integrated into butchery and processing of bowhead whales and therefore may provide indirect evidence of these important economic processes. Second, the industry figured prominently in the carefully scheduled Nuvugarmiut seasonal tool production strategy, and it was directly related to aspects of seasonal mobility and logistics. Third-and perhaps most importantly - as durable evidence of the proceeds of the whale hunt, bowhead bone, especially if worked, is linked to socioeconomic aspects of redistribution, status, and trade. In fact, the potential surplus that whaling provides must be considered a fundamental socioeconomic determinant of Neoeskimo whaling societies (Sheehan, 1995). The value of whale bone as a potential surplus commodity is reflected in the fact that, along with baleen, it was considered the property of North Alaskan umialit (Whitridge, 2002). Because most of the perishable products of the bowhead hunt are not preserved archaeologically, the study of whale bone implements and their manufacture and circulation may be essential to reconstructing social and redistributive networks within whaling societies and between whaling societies and adjacent groups. This preliminary study addresses these issues only tangentially, and indeed raises many more questions about these aspects of Mackenzie Inuit society than it has answered. Only through continued analysis of bowhead bone assemblages recovered from structures like those at McKinley Bay and integration of this information into larger intra- and inter-site studies can these topics be addressed.

\section{ACKNOWLEDGEMENTS}

This paper was written at the Canadian Museum of Civilization in Gatineau, with financial support provided by a Social Sciences and Humanities Research Council of Canada (SSHRC) postdoctoral grant. I owe a debt of gratitude to Charles Arnold, who both suggested McKinley Bay as a postdoctoral project and supported the fieldwork there. David Morrison, Robert McGhee, Max Friesen, and James Savelle offered helpful (and much appreciated) advice during the initial stages of research and writing. Special thanks go to Karen Ryan, who provided much needed guidance on an earlier draft. The Polar Continental Shelf Project, the Northern Scientific Training Program (NSTP), the Aurora Research Institute, and the Social Sciences and Humanities Research Council of Canada (SSHRC) kindly supported the fieldwork conducted at McKinley Bay. Thanks to Karen McCullough, Cristyann Darwent, and two anonymous reviewers for their helpful editorial and substantive comments.

\section{APPENDIX: \\ THE MACKENZIE INUIT BOWHEAD BONE REDUCTION SEQUENCE}

\section{Primary Reduction (Core and Blank Production)}

Rib Extraction

1a) Cut connective tissue at head and tubercle of rib to separate rib from vertebrae

or

1b) Chop and snap head, freeing remaining rib from vertebral column

2) Cut and chop meat away from ribs and vertebrae

Transverse Reduction

1) Chop and snap transversely to free large distal blank

2a) Chop and snap transversely below tubercle to free proximal blank and central section and/or

2b) Chop and snap transversely above tubercle to free proximal blank and central section

Produces large central rib section, large distal rib blank, and one or two smaller proximal rib blanks

Longitudinal Reduction (Central Rib Section)

1) Chop or chip to remove lateral margins (creates a rib core)

2) Split along trabecular layer to isolate cortical halves

3) Chop or chip away excess trabecular material

4) Chop or whittle lateral margins to desired width

5) Chop and snap transversely to remove rough ends (producing one or more small cortical blanks) and/or

6) Chop and snap transversely to desired length

Produces two or more long cortical blanks 
Secondary Reduction (Preform Production and

Tool Manufacture)

Cortical Rib Blank (e.g., Sled Shoe)

1) Chop and whittle lateral and end margins to straighten into preform

2) Chop or whittle trabecular surface to smooth and straighten

3) Chop or whittle cortical surface to smooth and straighten

4) Grind and/or polish surface to smooth

5) Drill peg holes

Distal Rib Blank (Mattock Blade)

1a) Chop or whittle proximal end and/or

2b) Chop or whittle distal end to form blade (establishes length of pick)

3) Chop and whittle lateral grooves to form notches

4) Scarify obverse and reverse for lashing

Proximal Rib Blank (e.g., Harpoon Head or Adze Head)

1a) Scrape and whittle cortical bone, avoiding trabecular layer, to produce tool preform or

1b) Groove along trabecular layer and snap to create cortical blank (Kitigaaryuit only)

- Chop and chip away remaining trabecular layer - Whittle to produce tool preform

2) Grind and/or polish the surface

3) Drill line hole and socket (large-gauge bit)/Drill distal socket pilot holes (large-gauge bit)

4) Drill blade slot pilot holes (small-gauge bit)/Drill ventral socket pilot holes (large-gauge bit)

5) Groove or whittle out blade slot/Groove or whittle out adze socket

\section{REFERENCES}

ARNOLD, C. 1990. Archaeological investigations at Saunaktuk. Manuscript on file, Prince of Wales Northern Heritage Centre, Box 1320, Yellowknife, Northwest Territories X1A 2L9.

1992. Report on the 1991 activities of the Mackenzie Delta Heritage Project: Excavations at McKinley Bay. Manuscript on file, Prince of Wales Northern Heritage Centre, Box 1320, Yellowknife, Northwest Territories X1A 2L9.

BETTS, M. 2000. Opportunism, optimality, and the origin of species: An investigation of Thule subsistence on Herschel Island, Yukon Territory. MA Thesis, Department of Anthropology, University of Toronto, Ontario.

. 2001. Review of faunal analyses at the Kuupuk (NiTs-1) and Pond (NiTs-2) sites, 1985 - 1995. Manuscript on file, Prince of Wales Northern Heritage Centre, Box 1320, Yellowknife, Northwest Territories X1A 2L9.

2004. A multicontextual approach to zooarchaeology:

Procurement strategies in the Mackenzie Delta Region, Western Canadian Arctic. PhD Thesis, Department of Anthropology, University of Toronto, Ontario. 2005a. Seven focal economies for six focal places: The development of economic diversity in the Western Canadian Arctic. Arctic Anthropology 42(1):47-87.

2005b. The McKinley Bay Archaeology Project: Description of the 2004 field season. Manuscript on file, Prince of Wales Northern Heritage Centre, Box 1320, Yellowknife, Northwest Territories X1A 2L9.

BINFORD, L.R. 1977. Forty-seven trips: A case study in the character of archaeological formation processes. In: Wright, R.V., ed. Stone tools as cultural markers: Change, evolution and complexity. Atlantic Highlands, New Jersey: Humanities Press, Inc. 24-38.

CARMACK, E.C., and MACDONALD, R.W. 2002. Oceanography of the Canadian shelf of the Beaufort Sea: A setting for marine life. Arctic 55(Supp. 1):29-45.

CORBIN, J.E. 1975. Aniganigaruk: A study in Nunamiut Eskimo archaeology. PhD Thesis, Department of Anthropology, Washington State University, Pullman, Washington, USA.

DAMAS, D. 1969. Environment, history and Central Eskimo society. In: Ecological essays: Proceedings of the Conference on Cultural Ecology, Ottawa 1966. National Museum of Canada Bulletin 230:40-64.

FRIESEN, T.M. 1989. Analysis of beluga bone from Gupuk (NiTs-1). Unpubl. manuscript on file, Prince of Wales Northern Heritage Centre, Box 1320, Yellowknife, Northwest Territories X1A 2 L9.

. 1992. Qikiqtaruk 1991: Archaeological investigations on Herschel Island, Yukon Territory. Manuscript on file at the Archaeological Survey of Canada, Canadian Museum of Civilization, 100 Laurier Street, P.O. Box 3100, Station B, Gatineau, Quebec J8X 4H2.

- 1995. "Periphery" as centre: Long-term patterns of intersocietal interaction on Herschel Island, northern Yukon Territory. PhD Thesis, Department of Anthropology, McGill University, Montreal, Quebec.

FRIESEN, T.M., and BETTS, M. 2005. Archaeofaunas and architecture: Zooarchaeological variability within an Inuit semisubterranean house, Arctic Canada. In: Maltby, M., ed. Integrating zooarchaeology. Oxford: Oxbow Books. 65-76.

FRIESEN, T.M., and HUNSTON, J. 1994. Washout-the final chapter: 1985-86 NOGAP salvage excavations on Herschel Island. In: Pilon, J.-L., ed. Bridges across time: The NOGAP Archaeology Project. Occasional Paper 2. Ottawa: Canadian Archaeological Association. 39-60.

FORD, J. 1959. Eskimo prehistory in the vicinity of Point Barrow, Alaska. Anthropological Papers of the American Museum of Natural History 47(Part 1).

GIDDINGS, J.L. 1952. The Arctic Woodland Culture of the Kobuk River. Philadelphia: The University Museum, University of Pennsylvania.

HUMPHREY, J., and HUTCHINSON, D. 2001. Macroscopic characteristics of hacking trauma. Journal of Forensic Science 46(2):228-233.

LEMOINE, G. 1991. Experimental analysis of the manufacture and use of bone and antler tools among the Mackenzie Inuit. PhD Thesis, Department of Archaeology, University of Calgary, Alberta. 
1994. Use wear on bone and antler tools from the Mackenzie Delta, Northwest Territories. American Antiquity 59(2): 316-334.

LEMOINE, G., and DARWENT, C. 1998. The walrus and the carpenter: Late Dorset ivory working in the High Arctic. Journal of Archaeological Science 25:73-83.

LEVY, R., DAWSON, P., and ARNOLD, C. 2004. Reconstructing traditional Inuit house forms using three-dimensional interactive computer modeling. Visual Studies 19(1):26-35.

McCARTNEY, A. 1995. Whale size selection by precontact hunters of the North American Western Arctic and Subarctic. In: McCartney, A., ed. Hunting the largest animals: Native whaling in the Western Arctic and Subarctic. Studies in Whaling 3, Occasional Paper 36. Edmonton, Alberta: Canadian Circumpolar Institute. 83-108.

McCARTNEY, A., and SAVELLE, J. 1985. Thule Eskimo whaling in the central Canadian Arctic. Arctic Anthropology 22:37-58.

McGHEE, R. 1974. Beluga hunters: An archaeological reconstruction of the history and culture of the Mackenzie Delta Kittegaryumiut. Newfoundland Social and Economic Studies 13. St Johns: Memorial University of Newfoundland.

1977. Ivory for the sea woman: The symbolic attributes of a prehistoric technology. Canadian Journal of Archaeology $1: 141-149$.

M'CLURE, R. 1969. The discovery of the North-West passage, ed. S. Osborn. Edmonton: Hurtig.

MONKS, G. 2001. Quit blubbering: An examination of Nuu' chah' nulth (Nootkan) whale butchery. International Journal of Osteoarchaeology 11:136-149.

MORRISON, D. 1986. Inuit and Kutchin bone and antler industries in northwestern Canada. Canadian Journal of Archaeology 10:107-125.

1988. The Kugaluk site and the Nuvorugmiut. Archaeological Survey of Canada Mercury Series Paper 137. Gatineau, Quebec: Canadian Museum of Civilization.

1990. Iglulualumiut prehistory: The lost Inuit of Franklin

Bay. Archaeological Survey of Canada Mercury Series Paper

142. Gatineau, Quebec: Canadian Museum of Civilization.

- 1994. An archaeological perspective on Neoeskimo economies. In: Morrison, D., and Pilon, J.-L., eds. Threads of Arctic prehistory: Papers in honour of William E. Taylor, Jr. Archaeological Survey of Canada Mercury Series Paper 149. Gatineau, Quebec: Canadian Museum of Civilization. $311-324$.

- 1997. An ethnohistory of the Inuvialuit from earliest times to 1902. Revista de Arqueología Americana 12:29-54.

. 2000. Inuvialuit fishing and the Gutchiak site. Arctic Anthropology 1:1-42.

MORRISON, D., and WHITRIDGE, P. 1997. Estimating the age and sex of caribou from mandibular measurements. Journal of Archaeological Science 24:1093-1106.

MURDOCH, J. 1892 [1988]. Ethnological results of the Point Barrow expedition. Reprint ed. Washington, D.C.: Smithsonian Institution Press.

NAGY, M. 1990. Caribou exploitation at the Trail River site, northern Yukon. Occasional Papers in Archaeology 2. Whitehorse: Yukon Heritage Branch.
1991. Bone and antler tools from a Late Prehistoric Mackenzie Inuit site. In: Cinq-Mars, J., and Pilon, J.-L., eds. NOGAP Archaeology Project: An integrated archaeological research and management approach. Occasional Paper 1. Ottawa: Canadian Archaeological Association. 45-53.

NELSON, E. 1899 [1983]. The Eskimo about Bering Strait. Washington, D.C.: Smithsonian Institution Press.

RICHARDSON, J. 1851. Arctic searching expedition, Vol. 1. London: Longmans, Brown, Green, and Longmans.

SAVELLE, J. 1997. The role of architectural utility in the formation of archaeological whale bone assemblages. Journal of Archaeological Science 24:869-885.

SAVELLE, J., and McCARTNEY, A. 1991. Thule Eskimo subsistence and bowhead whale procurement. In: Stiner, M., ed. Human predators and prey mortality. Boulder, Colorado: Westview Press. 201-216.

. 1994. Thule Inuit bowhead whaling: A biometrical analysis. In: Morrison, D., and Pilon, J.-L., eds. Threads of Arctic prehistory: Papers in honour of William E. Taylor, Jr. Archaeological Survey of Canada Mercury Series Paper 149. Gatineau, Quebec: Canadian Museum of Civilization. 149-281.

. 1999. Thule Eskimo bowhead whale interception strategies. World Archaeology 30:437-451.

SAVOIE, D. 1970. The Amerindians of the Canadian Northwest in the 19th century, as seen by Emile Petitot, Vol. 1: The Tchiglit Eskimos. Ottawa: Department of Indian and Northern Affairs.

SCHEINSOHN, V., and FERRETTI, J.L. 1995. The mechanical properties of bone materials in relation to the design and function of prehistoric tools from Tierra del Fuego, Argentina. Journal of Archaeological Science 22:711-717.

SHEEHAN, G. 1995. Whaling surplus, trade, war, and the integration of prehistoric northern and northwestern Alaskan economies, AD 1200-1862. In: McCartney, A., ed. Hunting the largest animals: Native whaling in the Western Arctic and Subarctic. Studies in Whaling 3, Occasional Paper 36. Edmonton, Alberta: Canadian Circumpolar Institute. 185-206.

STEFANSSON, V. 2001. Writing on ice: The ethnographic notebooks of Vilhjalmur Stefansson, ed. G. Palsson. Hanover, New Hampshire: University Press of New England.

STENTON, D., and PARK, R. 1994. Formation processes and Thule archaeofaunas. In: Morrison, D., and Pilon, J.-L., eds. Threads of Arctic prehistory: Papers in honour of William E. Taylor, Jr. Archaeological Survey of Canada Mercury Series Paper 149. Gatineau, Quebec: Canadian Museum of Civilization. $409-422$.

SWAYZE, K. 1994. The Tuktoyaktuk Peninsula interior: Precontact Inuvialuit land use. In: Pilon, J.-L., ed. Bridges across time: The NOGAP Archaeology Project. Occasional Paper 2. Ottawa: Canadian Archaeological Association. 127-150.

VANSTONE, J. 1962. Point Hope: An Eskimo village in transition. Seattle: University of Washington Press.

WHITRIDGE, P. 2001.Zen fish: A consideration of the discordance between artifactual and zooarchaeological indicators of Thule Inuit fish use. Journal of Anthropological Archaeology 20(3): $3-72$. 
144 • M.W. BETTS

2002. Social and ritual determinants of whale bone transport at a Classic Thule winter site in the Canadian Arctic. International Journal of Osteoarchaeology 12:65-75.

YERKES, R., and KARDULIAS, P. 1993. Recent developments in the analysis of lithic artifacts. Journal of Archaeological Research 1(2):89-119.
YORGA, B. 1980. Washout: A Western Thule site on Herschel Island, Yukon Territory. Mercury Series Paper 98. Ottawa: Archaeological Survey of Canada. 